\title{
Technological adaptation to harmful algal blooms : socioeconomic consequences for the shellfish farming sector in Bourgneuf Bay (France)
}

\author{
José A. Pérez Agúndez ${ }^{a}{ }^{,}$, Pascal Raux ${ }^{b}$, Sophie Girard ${ }^{a}$ and Rémi Mongruel ${ }^{a}$
}

\author{
${ }^{\text {a }}$ Ifremer , UMR, AMURE, Plouzané , France \\ ${ }^{\mathrm{b}}$ Université de Brest, UMR, AMURE, OSU-IUEM, Brest, France \\ *: Corresponding author : José A. Pérez Agúndez, email adress : jose.perez@ifremer.fr
}

\begin{abstract}
:
The economic impacts of harmful algal blooms (HABs) on the shellfish farming sector depend on their frequency, duration and intensity. Safeguarding storage and accelerated detoxification are technical solutions that could mitigate the effects of these events. This article first analyzes the economic feasibility of the technological changes that can be adopted by the shellfish farming sector in France. It then examines their associated social impacts. Finally, an application is carried out on the Bourgneuf Bay production area. The economic analysis addresses three issues related to HABs: (1) the economic performance of the shellfish farms in Bourgneuf Bay, (2) the costs of these new technologies, and (3) the economic viability of such an investment. Results suggest that only a few economically viable farms would be able to implement these technologies, yet this would not be an option for smaller, less profitable farms. Individual action within the context of a "laissez-faire" public policy, taking into account the need for technological equipment, would result in a concentration of the sector to the benefit of the largest capitalist farms, with negative effects on employment and the distribution of economic rent. Alternative ways for implementing these technological changes would require collective actions or public support.
\end{abstract}

Keywords: detoxification ; economic viability ; harmful algal blooms ; safeguarding storage ; shellfish farming 


\section{Introduction}

Harmful algal blooms (HABs) are toxic environmental phenomena that generally affect coastlines. Their frequency has increased sharply in recent decades (Anderson, 1989; Van Dolah, 2000), although their origin is still poorly understood. In some coastal areas a correlation between these events and eutrophication processes has been noted (Sellner, 2003), but other climatic and hydrological factors may also play a key role (Hodgkiss and Ho, 1997). Since the eradication of these algal blooms is not possible (Wright, 1995), research focuses on forecasting their occurrence. Some models take into account environmental variables such as the concentration of nutrients, the direction and intensity of winds, exchanges in the water column, etc. (Wong et al., 2007; Wong et al., 2009).

These toxic blooms represent a threat for the biodiversity of coastal ecosystems (Van Dolah et al., 2001). They cause mortality and negative effects on the growth and reproduction of various biomasses (Sournia et al., 1990). Moreover, they also represent a threat to human health via the consumption of contaminated seafood. HABs produce three main categories of toxicity that pose a risk for human health. The first of these, Diarrheic Shellfish Poisoning (DSP), is caused by the ingestion of toxins produced by several diarrheal phytoplankton species of the genus Dinophysis. This type of shellfish poisoning is the most frequent and the least harmful for human health, mainly causing diarrhea. In the case of Paralytic Shellfish Poisoning (PSP), toxins are produced by Alexandrium minutum and $A$. catenella / tamarense phytoplankton. Their effects are more dangerous than DSP and can lead in extreme cases to neurological paralysis. Finally, with Amnesic Shellfish Poisoning (ASP), toxins are produced by several species of phytoplankton belonging to the genus Pseudo-nitzschia and result, notably, in short-term memory loss.

Shellfish farming is directly affected by algal blooms because shellfish feed on this harmful phytoplankton and therefore accumulate the toxins. In the absence of efficient warning mechanisms, European Regulation (EC) No. 854/2004 of the European Parliament and of the Council of April 29, 2004 recommends the implementation of a water quality monitoring system covering all production areas, with the objective of protecting human health. The monitoring protocols determine: (1) the quality of the water in production areas; (2) the requirements of farms concerning purification systems; and (3) the shellfish harvesting and sales ban procedures when water masses in a production area are contaminated. Such bans have economic repercussions on the shellfish farming industry resulting from delays in sales. In the short run, cash flow requirements can lead to financial costs. In the long run, damage to the sector's image can reduce demand, lead to lower prices and loss of revenue, and even, in extreme circumstances, result in bankruptcies and job losses.

HABs are random events and cannot always be accurately forecasted. Shellfish farms need to internalize the additional costs incurred by shellfish bans. In light of the recent increase in the occurrence of HAB events, technical responses such as safeguarding storage and accelerated detoxification processes will be discussed as potential solutions to mitigate the economic impacts of these bans. Safeguarding storage consists in storing shellfish in noncontaminated water. This ensures the protection of the livestock to be sold before any water contamination can take place and allows its sale during shellfish bans. Conditions required for implementing these processes include: (1) the availability to shellfish farms of noncontaminated water (well water sources); (2) the existence of efficient warning mechanisms; and (3) traceability guarantees. Accelerated detoxification can be used after contamination of the livestock biomass. Detoxification of shellfish occurs naturally once their exposure to toxins disappears. This ability is linked to their natural biological capacity to eliminate toxins, but is also determined by environmental factors such as water temperature and salinity, etc. (Blanco et al., 1997). Moreover, under normal conditions, different species of shellfish will eliminate toxins at different rates, and the time required can have economic impacts on the 
farms concerned. Accelerated detoxification processes reduce the period of shellfish purification. According to experimental analysis of the detoxification kinetics of DSP, using high concentrations of nutrients (Lassus et al., 2002), Pacific oysters can completely eliminate toxins within six to seven days. These results are significantly better than those obtained by ozone water treatment (15-20 days). The results of detoxification kinetics using ozone water treatment are relatively close to those obtained by forced oxygenation without physical-chemical treatment of the water. Accelerated detoxification works efficiently when the following three conditions are met: (1) it should comply with health regulations (in the case of a shellfish ban, the contaminated stock can neither be harvested nor sold); (2) it must be economically viable, which directly depends on the additional costs associated with new investments; and (3) it requires continuous water quality control. These conditions involve a profound change in production processes. Moreover, consumer perception of product quality may be modified due to the shellfish having gone through a decontamination process.

From an economic point of view, the efficiency of production processes must be based on a cost-benefit analysis. The decision to implement a technological change requires a comparison of the associated costs (including investment and operational costs) with the expected benefits. In the case of shellfish bans due to HAB events, new investments do not result in any real benefits. However, while farms will not make any extra income from the use of the new processes, their objective is to maintain revenues, even during ban periods.

The technological changes considered in this paper rely on individual or collective initiatives. Investments can be supported individually by each shellfish farm or can be shared by a pool of farms with the objective of decreasing unitary costs through economies of scale. The choice will depend on the capacity of the farms concerned to make additional investments, and on the willingness of the sector to accept structural changes in production processes. A complementary scenario to be considered is the emergence of companies specialized in the purification of shellfish. This specialization aims to optimize the detoxification processes, thus reducing the associated cost across the whole sector (as in the case of the depuradures in Spain, companies specialized in the purification of mussels). However, technological changes are likely to have social impacts on the aquaculture industry, since the capacity of farms to support new investments is extremely heterogeneous. Some papers analyzing the implementation of new technologies for controlling fish farm effluents (e.g., Engle et al., 2004; Engle and Valderrama, 2003) demonstrate that small aquaculture farms are usually the most adversely affected by the increased costs resulting from technological changes. These farms, especially the most economically vulnerable among them, can be forced out of the industry. Moreover, the implementation of new regulations or more capitalist processes can also generate additional barriers to entry for small farms (Kouka and Engle, 1996). These social impacts will also be addressed in this paper.

\section{Technical Options for mitigating HAB Events}

The processes of contamination and purification of shellfish depend on the species. Under natural conditions, shellfish can be contaminated by bacteria, viruses or toxins. When these external agents disappear, shellfish require a longer or shorter period of time to depurate the toxins and return to their "normal" healthy state. Consequently, the economic problem caused by HABs is not a matter of biomass mortality, but rather a problem of access to the market and hence of decreased revenue during periods of outbreak. The choice of technical solution to address shellfish bans depends on the specific characteristics of the production area (temperature, availability of water sources, etc.) and the extent of HAB events. The technical options discussed are based on existing technologies primarily used for standard purification and storage before marketing. They are discussed in the following paragraphs. 
An illustration of a standard diagram of a recirculation system is detailed in Figure 1. More simple purification systems can be built from this global scheme.

\subsection{Safeguarding storage techniques}

Safeguarding storage consists in placing animals in external tanks before they are exposed to contamination. The availability of marketable oysters during shellfish bans would maintain revenues. Two main safeguarding storage processes can be identified. Firstly, recirculated treated water (cooling to $14^{\circ} \mathrm{C} / 57.2^{\circ} \mathrm{F}$ ) named $\mathbf{S 1}$, is a process which allows for keeping shellfish in closed tanks (for storage or purification) using seawater cooled to under $14^{\circ} \mathrm{C} / 57.2^{\circ} \mathrm{F}$. The operating process consists in filling the tank in an hour at the frequency of the safeguarding requirements. Recirculation, cooling and UV sterilization operate continuously (24/7) during safeguarding operations. The objective is to reduce the oysters' kinetic metabolism and consequently slow down and stop their nutrition system.

Secondly, the dry cold storage (S2) process allows storage of livestock in cold storage units at $4^{\circ} \mathrm{C} / 39.2^{\circ} \mathrm{F}$. No water is required. Oysters can be preserved several weeks out of water. The equipment required is a simple cold room with a storage capacity of $1 \mathrm{ton} / \mathrm{m}^{2}$. Equipment measuring $2 \mathrm{~m}$ in height represents a storage capacity of $500 \mathrm{~kg} / \mathrm{m}^{3}$. The cooler operates continuously (24/7) during safeguarding operations to maintain a constant temperature of $4^{\circ} \mathrm{C} / 39.2^{\circ} \mathrm{F}$.

\subsection{Accelerated detoxification techniques}

The equipment used for accelerating detoxification is very similar to that used for standard purification. These techniques require recirculated water to ensure healthy conditions for oysters, and are subject to the availability of well water. The temperature of the water must be controlled and its variation has to be maintained within a limit of $2^{\circ} \mathrm{C} / 35.6^{\circ} \mathrm{F}$ compared to pumped seawater. The oysters are fed continuously. Based on this common protocol, three different procedures can be distinguished according to whether the supply of phytoplankton is local (auto-production) or external (purchase). In case of auto-production, farms need to invest in specific material. Two technical options are possible. Firstly, phytoplankton is produced in outdoor tanks under natural light using well water, which is naturally rich in nutritive elements (D1). Secondly, phytoplankton is produced in indoor 300L cylinders using artificial light (D2). Seawater is pumped into the cylinders and nutritive elements are added.

The simplest way for farms to be supplied in phytoplankton is to externalize production by purchasing concentrated algal paste. This is option D3. This alternative leads to additional operational costs without requiring additional investments in equipment. The choice of producing or purchasing phytoplankton is determined by comparing their respective unitary costs. The technical description of the required equipment by technology is detailed in Table 1.

\section{Materials and Methods}

\subsection{Data sources}

The capacity of French shellfish farms to invest in innovative technologies for reducing the consequences of HABs is assessed in this paper. Our case study focuses on the oyster farms of the Bourgneuf Bay area (Pays de la Loire region, France). This economic analysis follows a three-step approach. Firstly, the structure and economic performances of the oyster farms in Bourgneuf Bay are assessed in order to evaluate their capacity to implement 
changes in production patterns. Secondly, the investments and operational costs associated with the different technical options are estimated. Thirdly, the economic feasibility for implementing technical options is explored. Several scenarios are developed, taking each technical option into consideration, and according to different durations of shellfish bans. We also distinguish between individual and collective actions in implementing technical options.

Two data sources were used to assess the viability of technological changes. The first database was provided by the Small-Scale Fishery Management Center (Centre de Gestion de la Pêche Artisanale, CGPA), which provides accounting services to fish and aquaculture farms. The initial database for Bourgneuf Bay comprised 579 annual financial reports for 81 farms between 1997 and 2007. At the end of the selection process, the database was reduced to 40 oyster farms, including only the farms specialized in oyster farming (at least $80 \%$ of their total revenues) and the farms which had filed a sufficient number of annual financial reports. For each of these selected farms, accounting indicators were assessed using arithmetic averages for the total period. Values were converted to 2007 constant US dollars (1.3705 \$/€).

The representativeness of the CGPA data was checked by comparing the sample to data from the national census of the shellfish farming industry (Girard et al., 2005). As regards the variables production, production surface area, and employment, calculated in full time equivalent (FTE) units, the data collected from CGPA can be considered as representative (Table 2).

The second source of data consists of technical and economic data, collected by a field study, from local professional organizations, support service companies, and aquaculture development experts. These data concern the description of the tanks used for the standard bacteriological purification systems used in the different production areas. These external tanks are additionally used for stocking production before sale. Safeguarding storage and accelerated detoxification technologies are based on comparable purification standards. The same tanks can be used for both of these processes, but their dimensions do not solely depend on sporadic HAB events, due to the high seasonality of shellfish production. The associated costs related to each technical option have been assessed from standard systems and taking into account the specificities of safeguarding storage or accelerated detoxification processes.

The data collected concern the purification systems of farms located in five production areas: three along the Atlantic coast of Brittany (the Etel river, Quiberon Bay, and the Pénerf river), and two along the Mediterranean coast (the Thau lagoon and the Salses-Leucate lagoon). The characteristics of the purification systems depend on the specificities of each production area, the size of the farm, and the technical requirements of each equipment option. The main criteria selected for building these technical options are the type of farm according to production volume $(10,20,50,100,200$ and 500 tons a year are distinguished), the individual volume of storage/purification tanks by type of farm, the average time of storage/purification, the storage/purification technique implemented, the storage capacity of each tank, the average seawater temperature measured in the area, the maximum duration of $\mathrm{HAB}$ contamination observed in the area and the maximum frequency of $H A B$ events observed in the area per year.

\subsection{Methods of extrapolating costs}

The unitary costs assessed for standard technologies will be extrapolated to the Bourgneuf Bay farms, depending on their requirements for safeguarding storage equipment. Costs are mainly related to tank size. In order to provide an efficient safeguarding mechanism, the tank must be of a size corresponding to its functionality and to the level of activity of the farm. There are two theoretical options that can be analyzed. In the first option (Option 1) tanks are 
considered as multifunctional. In this case, the primary purpose of the equipment is to stock shellfish for sale or for standard purification. Occasional safeguarding storage or accelerated detoxification processes may constitute a secondary storage function. The volume of the tanks is mainly determined by their primary function. Consequently, their size must allow for stocking the largest production volumes of the year (on average, $50 \%$ of oyster sales occur during the Christmas period). The storage capacity of the tanks during shellfish bans can, therefore, be considered as unlimited and hence independent of the duration of these bans. In the second option (Option 2), tanks are used specifically for safeguarding or detoxification. In this scenario, the farms only use the tanks for stocking shellfish during bans. This functionality can be justified in production areas with no administrative purification requirements and where the risk of shellfish bans is low. In such a case, the volume of the tanks can be adapted to the strict requirements for storage during HAB events. Scenarios of different durations have thus been taken into consideration.

In both cases, the previously assessed unitary costs of standard equipment, in US dollars per $\mathrm{m}^{3}$ of tank required per technology, including associated equipment, are used to evaluate the total costs that would be incurred by the Bourgneuf Bay farms if they decided to invest in external tanks for safeguarding and detoxification. In general, the investment cost per $\mathrm{m}^{3}$ decreases exponentially as the tank size increases linearly. For safeguarding techniques, this economy of scale (Figure 2) varies by a factor of up to three from the smallest to the largest farms. However, the relationship between operational costs and the size of equipment is relatively linear. The choice of equipment is then guided by each technical requirement (for example, the risk of shellfish bans, the volume of production, sales, etc.), as well as the investment capacity of the farms. The same kind of mathematical relationship is observed for other technical options, only the parameters change. As a result, the shape of the cost curve does not indicate any economic incentive to invest on the part of small farms.

The extrapolation of costs for each technical option was carried out for several scenarios that combine four main factors: farm size, duration of shellfish bans, tank functionality, and implementation strategy. The unitary costs assessed for safeguarding storage and accelerated detoxification processes are extrapolated for three types of oyster farms: small, medium and large. This segmentation is based on the size of the farms, and on the results of the financial analysis of the sampled farms (Section 4.1). The additional annual production costs related to each technological option are operational and depreciation costs. These costs are measured on the size of the equipment. If the profit made by a farm allows for remunerating the family workers and investing in new equipment, the option is considered to be economically feasible.

Two types of extrapolations were done based on different scenarios. The main criteria used for these scenarios are detailed in Table 3. The duration of shellfish bans is set at a maximum of eight weeks. Beyond this duration, additional costs are too high and implementing technical changes is not economically feasible. "Tank functionality" determines the required storage volume.

Moreover, the existence of economies of scale in safeguarding and detoxification processes leads to explore collective actions by testing the economic feasibility of sharing investments by several companies. This scenario is only tested for extrapolation in Option 2 (specific functionality of tanks). Storage volumes are much lower than those required for extrapolation in Option 1 (multifunctionality of tanks). Hence, the collective actions explored assess the breakeven point from which an association of oyster farms could efficiently manage the effects of HAB events. This scenario considers an association of farms belonging to the same category and presenting the same level of profitability (linear aggregated benefits curve in Figure 2). The extrapolation in Option 2 explores whether the implementation of each technology could be feasible individually at farm level. If this is not the case, the extrapolation assesses the threshold number of farms necessary to ensure the profitability of 
a collective investment. This is schematically illustrated in Figure 3 by the feasibility frontier of investments.

In the case of a collective action, the total costs associated with the shared investments can be supported by the aggregation of the profits of individual farms. The feasibility frontier $(x)$ represents the point from which a collective action is economically viable. It measures the number of farms $N_{\min }$ required for viability, which corresponds to the minimum tonnage of biomass treated in order to bring the average unitary cost of treatment under the profitability threshold. $N_{\max }$ is the maximum number of farms that could potentially participate in a collective investment. If $N_{\max }$ is below $N_{\min }$, the implementation of the new technology is not considered feasible, for either individual or collective strategies (case of $N_{\max 2}$, in Figure 2). If $N_{\min }$ is below $N_{\max }$, there are enough farms to participate in a collective action that would be economically feasible $\left(N_{\max 1}\right)$.

\section{Results}

The mitigation of the impacts of HAB events explored in this paper is based on the technical options identified. Their implementation is conditioned by technical requirements and economic feasibility. The capacity for oyster farms to cover additional costs is limited and is partially related to their profitability. The analysis of this capacity is based on the comparison of the costs associated with each new technical option with the economic surplus that could be allocated to balance these additional costs.

\subsection{Profitability of oyster farms in Bourgneuf Bay}

The shellfish farming sector of the Pays de la Loire region is basically structured around small farms primarily specialized in oyster production. Labor is mainly provided by the farmer and his family. Approximately $10 \%$ of farms are managed by full-time family co-owners. The owners' wives largely contribute to the family employment with an average of 0.5 FTE per farm. CGPA and national census indicators are therefore quite similar.

The assessment of the profitability of these oyster farms is based on their annual financial reports. The sampled farms have been segmented into three classes (small, medium and large) according to their production level. The "small" class (c1) comprises the 16 smallest farms producing less than 30 tons of oysters a year. The "medium" class (c2) comprises 17 farms producing between 30 and 60 tons of oysters a year. Finally, the "large" class (c3) comprises the seven largest farms of the sample producing more than 60 tons of oysters a year. The average annual values of the economic indicators are given in Table 4.

These farms' profits are primarily allocated to remunerate the family workforce, which generally does not have employee status. Any profits left over can be allocated to return on capital or to new investments. This overall allocation depends on the economic strategies of the farms, determined by their "life-cycle" and their profitability. The net profits presented in the last column of Table 4 measure the financial surplus which can potentially be allocated to new investments. The smallest farms (c1) generate very low profits and can only remunerate the family workforce, often at levels under current wage standards. They subsequently have no economic capacity to fund new investments. Medium-sized farms (c2) generate, on average, weak profits. Their capacity to invest is limited to the cheapest technical options required to manage the effects of short-term shellfish bans. Finally, the largest farms (c3) are the more profitable ones, but they also have a greater family workforce to remunerate. They have the highest capacity to implement new investments, but only if the additional associated costs are lower than US\$16,500. 


\subsection{Feasibility of technological changes in Bourgneuf Bay}

The extrapolation results of Option 1 (multifunctional tanks) show that the smallest farms (c1) have no capacity for adopting these technologies (Table 5). Only the safeguarding technology based on dry cold storage could be adopted by medium-sized farms (c2). This is the cheapest option as it does not require expensive equipment, with electricity being the only operational cost to be met. The largest farms (c3) have almost full capacity for individually implementing the complete range of technologies.

The extrapolation results of Option 2 (specific functionality of tanks) are related to the strict requirements of storage during $\mathrm{HAB}$ events. The cost assessments of safeguarding storage and accelerated detoxification are compared with the profitability of farms detailed in Table 4. As in Option 1, the smallest farms (class 1) do not have the capacity to implement any technical option, even the simplest one for short-term shellfish bans. The largest farms (class 3) have almost the full capacity to invest in all types of equipment. Only the more costly detoxification technologies (D2 and D3) cannot be afforded by these farms for shellfish bans lasting longer than five weeks (c.f. Table 6).

The profitability of class 2 farms is low. Their capacity for investing in additional new technologies fluctuates, depending on the cost of equipment. This capacity is explored though scenarios built on the combination of technical options and the size of equipment. The latter is conditioned by the size of the farm and the duration of the shellfish bans. The table 6 shows that $\mathrm{c} 2$ farms can invest in safeguarding storage techniques based on recirculation systems if the duration of the shellfish bans is no longer than two weeks. They also have the full capacity to invest in safeguarding techniques based on dry cold storage. Finally, their capacity for investing individually in detoxification systems is limited. This is only feasible for shellfish bans that do not exceed three weeks for option D1, one week for option D2, and two weeks for option D3. For the longest bans, the costs of the equipment required can be considered as prohibitive for most of the $\mathrm{c} 2$ farms.

In general, medium-sized farms (c2) are only able to individually invest in the case of shellfish bans of short duration. But the economies of scale characterizing the different technical options can encourage collective action, resulting in a decrease in the individual costs borne by each farm. Such options are explored through scenarios for the extrapolation in Option 2 and for $\mathrm{c} 2$ farms. The results are detailed in Table 7. The economic feasibility of implementing technical options according to different durations of shellfish bans is assessed in terms of farm numbers. A scenario rated 0 means that an option is not economically feasible, neither at an individual nor a collective level. A scenario rated 1 indicates economic feasibility at both individual and collective levels. Scenarios characterized by a number of farms greater than 1 mean that only technical options implemented in a collective way are economically feasible. The value is a breakeven point in terms of the lowest number of farms required to ensure the profitability of the technical option implemented under a collective investment and cost sharing system.

The assessments generally show that for class 2 farms, the economic capacity for implementing any technical option is feasible only for shellfish bans lasting no longer than one week per year. However, there is no real economic impact over such short periods. In this case, investments and the running costs of equipment would be higher than the loss of revenue incurred. In the case of a shellfish ban lasting two consecutive weeks, only option D2 is no longer economically viable if implemented individually. For bans lasting more than two weeks, option D3 is also no longer profitable, whatever its implementation level. For these two most expensive equipment options (D2 and D3), with a shellfish ban lasting longer than two weeks, farms cannot cover the associated costs, neither collectively nor individually. Option D1 remains viable individually for bans lasting up to three weeks, and collectively for between four weeks (two farms) and seven weeks (106 farms). Regarding storage, S2 is the 
only option viable at individual level, whatever the duration of the ban. Option S1 is viable individually for bans up to four weeks, and only viable under a collective action for bans beyond that duration: three farms for five weeks, six farms for six weeks, 13 farms for seven weeks, and 26 farms for bans lasting up to eight weeks.

Even if these results offer theoretical references of economic viability, not all of the technical options are necessarily suitable for all durations of shellfish bans. Thus, keeping animals in tanks without feeding or in dry cold storage is only feasible for limited periods, and with difficulty beyond two consecutive weeks. Only the most expensive systems can be technically feasible for the longest bans, but their costs cannot be borne by the majority of farms. The results also illustrate the breakeven point in terms of economic viability through the number of farms necessary to ensure this viability. But the approach also emphasizes that beyond individually viable options, the associated economies of scale also require collective action in order to improve the economic viability already observed at individual level.

\section{Conclusions and discussion}

The shellfish farming sector in Bourgneuf Bay is mainly comprised of small or micro highlyspecialized oyster farms, $90 \%$ of which produce less than 25 tons of oysters a year, with approximately one third producing only 10 tons a year. This structure suggests a weak capacity by the sector to support important technological changes. Beyond the dual structure of the shellfish farming sector, comprising both small and large farms, it is also highly heterogeneous in terms of farming practices, economic strategies related to marketing, provisioning, geographical diversification, species farmed, technical choices, etc. (Girard et al., 2009). Subsequently, the responses adopted by farms facing a similar risk are likely to be just as heterogeneous.

Considering the structure of the oyster farming sector in Bourgneuf Bay and the costs of the technological changes considered to reduce HAB effects, this paper has shown that the majority of the small farms would be excluded from the technological innovation process, even if collective actions were to be implemented. The economic viability of most new production processes may not be achieved, even in the case of public investment subsidies, due to exorbitant operational costs. Thus, coming back to the initial question of whether or not technological changes (such as those considered in this paper) are viable for the shellfish farming sector, the answer depends on two factors: the size of the farm and the implementation strategy. The majority of the farms in Bourgneuf Bay would not be able to cover the costs related to these new processes by themselves. However, in other regions, the ratio of farms able to adopt these changes could be higher and should be explored. In all cases, the capital intensification would accelerate the rate of farms leaving the sector. Only a collective response combining subsidies for the smallest farms, sharing of investments, or the emergence of new operators specializing in the treatment processes, could lead to a globally viable technical change for the whole sector. For example, due to economies of scale for safeguarding storage and accelerated detoxification, the aggregation of all equipment costs to a single producer at the scale of the production area would be economically viable. But a centralized and private purification system frequently generates a bottleneck for producers. Often managed by middlemen and combined with a sales channel, such systems tend to weaken the bargaining power of producers in terms of price (Raux, 2010). Local producer organizations and associations could avoid this bottleneck by working together to develop their own collective purification system. However, compared with centralized systems, experience highlights important governance difficulties over the long term when collective management is divided among several dozen producers. 
Many other intermediate situations should be explored but would require additional analyses integrating the industry's capacity to technically modify production processes. All of this must be considered in a context characterized today by fast changes in the sector, which generate high environmental and economic risks across the whole production chain.

Finally, this empirical case study suggests that any attempt to develop and spread technological innovations to mitigate environmental damage across the shellfish farming industry should clearly address the associated social and environmental consequences for four reasons. Firstly, technological changes are a way of minimizing environmental constraints in the production processes of biological resources. However, these strategies are restricted to the efficiency of the technology available. Secondly, as mentioned by Engle and Valderrama (2003), there is a trade-off between the cost to society of poor environmental quality and the costs of controlling and maintaining a high level of environmental quality. The priority for mitigating impacts can lead to reduced compliance with environmental quality standards. Thirdly, most shellfish farms are not able to implement complex technological innovations. This is mainly the case of small and traditionally familyrun farms. Only collective actions can be viable under certain conditions if there are enough agents to share the additional costs associated with these innovations and if the durations of shellfish bans are not too long. In the context of a "laissez-faire" public policy, the shift by the shellfish farming industry towards cultural and commercial practices which require more technological equipment would certainly lead to a concentration of the sector, to the benefit of the largest capitalist farms, with negative effects on employment and the distribution of economic rent. Lastly, technological innovation in primary sectors frequently benefits from public subsidies, at least in the initial stages of development. These policies often concern the whole sector, but the economic impacts of HABs are heterogeneous and depend on the vulnerability of the farms faced with these events. Exposure and sensitivity to HABs are not similar for all farms, and their resilience capacity is determined by different individual factors. Hence, industry-level policies are more efficient and less costly when they mainly target the more vulnerable farms.

\section{Acknowledgments}

This work was conducted within the Gerrico project, a research project funded by the Pays de la Loire Region in France. The Authors would like to thank the CGPA and notably Laurent Le Grel for their support in the data collection process, and IDEE Aquaculture for providing its valuable cooperation in this work.

\section{References}

- Ami D., Rochaix L. Mareval O. and Rousset N. (2003). Evaluation des conséquences économiques de la gestion des risques sanitaires liés aux proliférations phytoplanctoniques marines / Entreprise Consult. - Paris : Entreprise Consult,. - $67 \mathrm{p}$.

- Anderson D. M., Hoagland P, Kaoru Y. and White A. W. 2000. Estimated annual economic impacts from harmful algal blooms (HABs) in the United States. WHOI-2000-11. Department of Biology, Woods Hole Oceanographic Institution, Woods Hole, Massachusetts. 
- Anderson, D.M. 1989. Toxic algal blooms and red tides: a global perspective. pp. 11-16, In: Okaichi, T., D.M. Anderson, and T. Nemoto (Eds.), Red Tides: Biology, Environmental Science and Toxicology. Elsevier

- Belin C., 2003. Bilan sur 20 ans des interdictions administratives de vente et de ramassage des coquillages, pour présence de phycotoxines, sur le littoral français 1984 2003. Brest, Ifremer. 79 p.

- Blanco J., Moroño A., Franco J., Reyero M. I. PSP detoxification kinetics in the mussel Mytilus galloprovincialis. One and two compartment models and the effect of some environmental variables. Mar. Ecol. Prog. Ser., 158, 165-175

- Corrales, R.A., \& Maclean J.L., 1995. Impacts of harmful algae on seafarming in the AsiaPacific areas. J. Appl. Phycol. 7:151-162

- Engle C. R., Pomerleau S., Fornshell G., Hinshaw J.M., Sloan D., Thompson S., 2005. The economic impact of proposed effluent treatment options for production of trout Oncorhynchus mykiss in flow-through systems. Aquacultural Engineering 32 (2005) 303323.

- Engle, C., Valderrama, D., 2003. Farm-level costs of settling basins on commercial catfish farms. Aquaculture. Eng. 28, 1-29.

- Girard S., Pérez Agúndez J.A., Miossec L., and Czerwinski, N. 2005. Recensement de la conchyliculture 2001. Agreste cahiers, numéro 1, février 2005. Paris: MAAPAR, Direction des affaires financières, SCEES.

- Girard S., Pérez Agúndez J.A., Van Iseghem S., (2009) « Typologie d'entreprises conchylicoles : Analyse à partir des données du recensement de la conchyliculture française 2002 ». Publications électroniques Amure, Série Rapport, R-14-2009. (http://www.umr-amure.fr/electro_rapports_amure/R_14_2009.pdf)

- Hoagland, P., D.M. Anderson, Y. Kaoru and A.W. White, 2002: The economic effects of harmful algal blooms in the United States: Estimates, assessment issues, and information needs. Estuaries, 25(4b), 819-837.

- Hodgkiss and Ho, 1997. Are changes in N:P ratios in coastal waters the key to increased red tide blooms? Hydrobiologia Volume 352, Numbers 1-3 / septembre 1997 Pages 141147

- Kouka, P.J., Engle, C.R., 1996. Economic implications of treating effluents from catfish production. Aquaculture Engineering 15 (4), 273-290.

- Larkin, S., and C. Adams, 2007. "Harmful Algal Blooms and Coastal Business: Economic Consequences in Florida." Society and Natural Resources. Volume 20, Number 9, October 2007 , pp. 849-859

- Lassus P., Bardouil M., Beliaeff B., Bougrier S. [et al.]. Coquillages contaminés par des phycotoxines paralysantes : vers une procédure de détoxification. Plouzané: Ifremer, 2002. - $47 \mathrm{p}$.

- Pérez Agúndez J.A., Mongruel R., Girard S., Cochet J.M., (2010). "Viabilité économique des procédés de sauvegarde et détoxification accélérée de coquillages cultivés face aux efflorescences de microalgues toxiques", Publications électroniques Amure, Série Rapports R-16-2010, 66 p.

- Raux P. 2010. "Socio-economic assessment of extensive polyculture - Esteros", Sustainable Extensive and Semi-Intensive Coastal Aquaculture in Southern Europe (SEACASE), EC FP6 Project Nº 044483, Deliverable D30, 16p.

- Sellner K. G., J. Doucette G. and Kirkpatrick G. J., 2003. Harmful algal blooms: causes, impacts and detection. Journal of Industrial Microbiology and Biotechnology. Volume 30, Number 7 / juillet, 383-406 p.

- Sournia A., Belin C., Berland B., Erard-Le Denn E., Grzebyk D., Marcailou C., Lassus P. and Partensky F., (1990). Nuisances et intoxications causées en France par le phytoplancton et les "efflorescences" marines : programme national "Efflorescences algales marines" : synthèse préliminaire. - Brest: Ifremer, 1990. - $25 \mathrm{p}$.

- Sournia A., Belin C., Berland B., Erard-Le Denn E., Grzebyk D., Marcailou C., Lassus P. and Partensky F., (1990). Nuisances et intoxications causées en France par le 
phytoplancton et les " efflorescences" marines : programme national "Efflorescences algales marines" : synthèse préliminaire. - Brest: Ifremer, 1990. - 25 p.

- Stolte W., Scatasta S., Granéli E., Weikard, H.P., van lerland, E. 2003. Socio-economic impact of harmful algal blobs in European Marine Waters. First deliverable for the Ecoharm project, 100 p. (http://www.bom.hik.se/ecoharm/deliverables/ecoharm.pdf)

- Todd, E. C. D. 1995. Estimated costs of paralytic shellfish, diarrhetic shellfish and ciguatera poisoning in Canada, p. 831-834. In P. Lassus, G. Arzul, E. Erard, P. Gentien, and C. Marcaillou (eds.). Harmful Marine Algal Blooms. Intercept Ltd., Paris, France.

- Van Dolah F.M., 2000. Marine Algal Toxins: Origins, Health Effects, and Their Increased Occurrence. Environmental Health Perspectives Supplements Volume 108, Number S1, March

- Wong K.T.M., Lee J.H.W. and Harrison P.J., 2009. Forecasting of environmental risk maps of coastal algal blooms. Harmful algae. 2009, vol. 8, n³, pp. 407-420

- Wong K.T.M., Lee J.H.W. and Hodgkiss I.J. A simple model for forecast of coastal algal blooms, Estuarine, Coastal and Shelf Science 74 (2007), pp. 175-196

Wright, J.L.C., 1995. Dealing with seafood toxins: present approaches and future options. Food Research International. Volume 28, Issue 4, 1995, Pages 347-358 
Tables

Table 1. Equipment specifications by technology

\begin{tabular}{|c|c|c|c|c|c|c|c|}
\hline & & Tec & & $\mathrm{al} \mathrm{c}$ & & & \\
\hline Equipment specifications by technology & 1 & 2 & 3 & 4 & 5 & & 7 \\
\hline Unfloodable concrete tank (water depth: $1 \mathrm{~m}$ ) & $\mathbf{x}$ & $\mathbf{x}$ & $\mathbf{x}$ & $\mathbf{x}$ & & & \\
\hline $\begin{array}{l}\text { Pump for renewed water supply. Flow rate: } 5 \mathrm{~m} \text { in } 1 \text { hour. Yield } \\
\text { considered }=0.7 \text {. }\end{array}$ & $\mathbf{x}$ & $\mathbf{x}$ & & $\mathbf{x}$ & $\mathrm{x}$ & & $x$ \\
\hline $\begin{array}{l}\text { Water recirculation pump (flow rate of } 100 \% \text { of the tank volume per } \\
\text { hour at a height of } 12 \mathrm{~m} \text { ). Yield considered }=0.7 \text {. }\end{array}$ & & & $\mathbf{x}$ & & & & $x$ \\
\hline $\begin{array}{l}\text { Cooler (water/air cooling considering a } 0.3^{\circ} \mathrm{C} \Delta \mathrm{T}^{\circ} \mathrm{C} \text { on the } \\
\text { recirculating water flow). Performance coefficient considered }=3 \text {. }\end{array}$ & & & & $\mathbf{x}$ & $\mathrm{x}$ & & $\mathbf{x}$ \\
\hline Recirculation systems in PVC (water circulation speed $<2 \mathrm{~m} / \mathrm{s}$ ) & & $\mathbf{x}$ & & & & & \\
\hline Renewed water net in PVC (water circulation speed $<2 \mathrm{~m} / \mathrm{s}$ ) & & & $\mathbf{X}$ & & & & \\
\hline Water circulation net in PVC (water circulation speed $<2 \mathrm{~m} / \mathrm{s}$ ) & & & & $\mathbf{x}$ & $\mathrm{x}$ & & \\
\hline $\begin{array}{l}\text { UV sterilizer for water circulation systems (germicide dosage of } \\
\left.25 \mathrm{~m} / \mathrm{cm}^{2}\right)\end{array}$ & & & $\mathbf{X}$ & & & & \\
\hline UV sterilizer for closed systems (germicide dosage of $25 \mathrm{~mJ} / \mathrm{cm}^{2}$ ) & & & & $\mathbf{x}$ & $\mathrm{x}$ & & $x$ \\
\hline Sand filter (transitory speed $<50 \mathrm{~m} / \mathrm{h}$ ) for closed water circulation & & & & $\mathbf{x}$ & $\mathrm{x}$ & & $\boldsymbol{x}$ \\
\hline Sand filter (transitory speed $<30 \mathrm{~m} / \mathrm{h}$ ) for circulated water circulation & & & $\mathbf{X}$ & & & & \\
\hline $\begin{array}{l}\text { Cooler (water/air cooling considering a } 0.2^{\circ} \mathrm{C} \Delta \mathrm{T}^{\circ} \mathrm{C} \text { on the } \\
\text { recirculating water flow). Performance coefficient considered }=3 \text {. }\end{array}$ & & & & $\mathbf{x}$ & & & \\
\hline $\begin{array}{l}\text { Cooler (water/air cooling considering a } 0.3^{\circ} \mathrm{C} \Delta \mathrm{T}^{\circ} \mathrm{C} \text { on the } \\
\text { recirculating water flow). Performance Coefficient considered }=3 \text {. }\end{array}$ & & & & & $\mathrm{x}$ & & \\
\hline Cool room allowing to store $1 \mathrm{~T} / \mathrm{m} 2$ (height of $2 \mathrm{~m}$ or $500 \mathrm{~kg} / \mathrm{m} 3$ ) & & & & & & & \\
\hline Cool room with ceiling light maintaining the temperature at $4^{\circ} \mathrm{C}$ & & & & & & & \\
\hline
\end{tabular}

(1) Standard purification I: sequential filling (untreated and non-oxygenated water)

(2) Standard purification II: sequential filling (untreated oxygenated water)

(3) Standard purification III: open systems with treated water

(4) Standard purification IV: recirculation system with treated water

(5) Safeguarding storage I: recirculation system with treated water

(6) Safeguarding storage II: dry cold storage

(7) Accelerated detoxification 
Table 2. Population of oyster farms in the Pays de la Loire Region (CGPA sample and 2001 national census)

\begin{tabular}{lrr}
\hline & $\begin{array}{r}\text { CGPA } \\
\text { sample }\end{array}$ & $\begin{array}{c}\text { National } \\
\text { census }\end{array}$ \\
\hline Number of farms & 40 & 320 \\
Estimated Production $(\mathrm{t})$ & \pm 25 & 23.04 \\
Surface area $(\mathrm{Ha})$ & 4.65 & 3.51 \\
FTE & 2.43 & 2.34 \\
\hline
\end{tabular}

(Estimated production in tons; SURF: production surface in hectares; FTE: labor measured in full time equivalent units)

Source: Girard et al. 2005 and CGPA

Table 3. Extrapolation scenarios explored

\begin{tabular}{lll}
\hline Criteria & Option 1 & Option 2 \\
\hline Farm size & Small/Medium/Large & Small/Medium/Large \\
Shellfish ban duration & & 1 to 8 weeks \\
Functionality of tanks & multifunctional & specific \\
Implementation & individual & individual and collective \\
\hline
\end{tabular}

Table 4. Economic indicators, CGPA sample (in 2007 US dollars)

\begin{tabular}{crrrrrrrr}
\hline Farm type & Number & Turnover & IC & AV & Wages & $\begin{array}{c}\text { Gross } \\
\text { profit }\end{array}$ & Family labor & $\begin{array}{c}\text { Net } \\
\text { profit }\end{array}$ \\
\hline c1 & 16 & 90,756 & 32,943 & 59,522 & 16,499 & 27,740 & 1.56 & none \\
c2 & 17 & 134,145 & 38,714 & 100,386 & 30,690 & 50,650 & 1.71 & 3,805 \\
c3 & 7 & 267,741 & 83,417 & 190,532 & 88,292 & 66,587 & 1.83 & 16,447 \\
\hline
\end{tabular}

N.B.: IC = intermediary costs; $A \mathrm{~V}=$ added value; Gross profit: difference between revenue and costs, Wages: including social taxes; Family labor: measured in full time equivalent units; Net profit: capital remuneration after paying family labor

Source: CGPA 
Table 5. Cost assessment extrapolation of technological changes for the oyster farms in Bourgneuf Bay using Option 1 (in 2007 US dollars)

\begin{tabular}{|c|c|c|c|c|}
\hline Technical option & Farm type & $\begin{array}{l}\text { Annual } \\
\text { profit* }\end{array}$ & $\begin{array}{l}\text { Investment } \\
\text { costs }\end{array}$ & $\begin{array}{l}\text { Annual } \\
\text { costs** }\end{array}$ \\
\hline \multirow[t]{3}{*}{ S1 (Recirculation system with treated water) } & c1 & 0 & 75,061 & 8,922 \\
\hline & c2 & 3805 & 99,383 & 11,838 \\
\hline & c3 & 16,447 & 143,436 & 17,135 \\
\hline \multirow{3}{*}{ S2 (Dry cold storage) } & $\mathrm{c} 1$ & 0 & 31,648 & 3,137 \\
\hline & c2 & 3,805 & 39,030 & 3,800 \\
\hline & c3 & 16,447 & 51,336 & 4,883 \\
\hline \multirow{3}{*}{$\begin{array}{l}\text { D1 (Recirculation system and phytoplankton } \\
\text { produced in outdoor tanks using well water) }\end{array}$} & $\mathrm{c1}$ & 0 & 76,238 & 7,814 \\
\hline & c2 & 3,805 & 101,500 & 10,372 \\
\hline & c3 & 16,447 & 147,984 & 15,051 \\
\hline D2 (Recirculation system and phytoplankton & $\mathrm{c} 1$ & 0 & 80,632 & 7,988 \\
\hline \multirow[t]{2}{*}{ produced in indoor $300 \mathrm{~L}$ cylinders) } & c2 & 3,805 & 109,409 & 10,662 \\
\hline & c3 & 16,447 & 164,974 & 15,566 \\
\hline D3 (Recirculation system and phytoplankton & $\mathrm{c} 1$ & 0 & 75,061 & 8,336 \\
\hline \multirow[t]{2}{*}{ paste purchased from suppliers) } & $\mathrm{c} 2$ & 3,805 & 99,383 & 11,232 \\
\hline & c3 & 16,447 & 143,436 & 16,523 \\
\hline
\end{tabular}

* potential investment capacity

** operational + capital depreciation costs 
Table 6. Assessment of annual costs by farm class (c1, c2, c3), technical option and duration of shellfish ban used in the extrapolation in Option 2 (in 2007 US dollars)

\begin{tabular}{|c|c|c|c|c|c|c|c|c|}
\hline Class & 1 week & 2 weeks & 3 weeks & 4 weeks & 5 weeks & 6 weeks & 7 weeks & 8 weeks \\
\hline & \multicolumn{8}{|c|}{ S1 (Recirculation system with treated water) } \\
\hline c1 & 741 & 1,320 & 1,852 & 2,354 & 2,836 & 3,303 & 3,756 & 4,200 \\
\hline c2 & 1,134 & 2,022 & 2,836 & 3,606 & 4,345 & 5,060 & 5,755 & 6,435 \\
\hline \multirow[t]{2}{*}{ c3 } & 1,830 & 3,264 & 4,580 & 5,824 & 7,018 & 8,173 & 9,297 & 10,395 \\
\hline & \multicolumn{8}{|c|}{ S2 (Dry cold storage) } \\
\hline c1 & 299 & 421 & 513 & 591 & 659 & 721 & 777 & 830 \\
\hline c2 & 385 & 540 & 659 & 759 & 846 & 925 & 998 & 1,066 \\
\hline \multirow[t]{2}{*}{ c3 } & 510 & 716 & 873 & 1,005 & 1,121 & 1,226 & 1,322 & 1,412 \\
\hline & \multicolumn{8}{|c|}{ D1 (Recirculation system and phytoplankton produced in outdoor tanks using well water) } \\
\hline c1 & 795 & 1,438 & 2,036 & 2,607 & 3,159 & 3,697 & 4,223 & 4,740 \\
\hline c2 & 1,230 & 2,229 & 3,159 & 4,049 & 4,910 & 5,749 & 6,570 & 7,376 \\
\hline \multirow[t]{2}{*}{ c3 } & 2,012 & 3,653 & 5,185 & 6,651 & 8,072 & 9,457 & 10,814 & 12,147 \\
\hline & \multicolumn{8}{|c|}{ D2 (Recirculation system and phytoplankton produced in indoor 300L cylinders) } \\
\hline c1 & 1,367 & 2,582 & 3,752 & 4,895 & 6,019 & 7,128 & 8,226 & 9,315 \\
\hline c2 & 2,183 & 4,135 & 6,019 & 7,861 & 9,675 & 11,467 & 13,242 & 15,001 \\
\hline \multirow[t]{2}{*}{ c3 } & 3,703 & 7,036 & 10,260 & 13,418 & 16,531 & 19,608 & 22,656 & 25,682 \\
\hline & \multicolumn{8}{|c|}{ D3 (Recirculation system and phytoplankton paste purchased from suppliers) } \\
\hline c1 & 1,269 & 2,386 & 3,458 & 4,503 & 5,529 & 6,541 & 7,541 & 8,531 \\
\hline c2 & 2,020 & 3,809 & 5,529 & 7,209 & 8,859 & 10,488 & 12,099 & 13,696 \\
\hline c3 & 3,414 & 6,457 & 9,391 & 12,259 & 15,082 & 17,869 & 20,628 & 23,364 \\
\hline
\end{tabular}

N.B.: in bold, the scenario assessed is not economically feasible 
Table 7. Feasibility frontier of technological change for $\mathrm{c} 2$ farms and the extrapolation in Option 2, in number of farms depending on technology and duration of shellfish bans

\begin{tabular}{cccccc}
\hline Duration of annual shellfish bans & S1 & S2 & D1 & D2 & D3 \\
\hline 1 week & 1 & 1 & 1 & 1 & 1 \\
2 weeks & 1 & 1 & 1 & 4 & 1 \\
3 weeks & 1 & 1 & 1 & 0 & 0 \\
4 weeks & 1 & 1 & 2 & 0 & 0 \\
5 weeks & 3 & 1 & 8 & 0 & 0 \\
6 weeks & 6 & 1 & 29 & 0 & 0 \\
7 weeks & 13 & 1 & 106 & 0 & 0 \\
8 weeks & 26 & 1 & 0 & 0 & 0 \\
\hline
\end{tabular}

N.B.: The figures in the table represent the threshold numbers of farms necessary to guarantee the economic viability of a technological change.

S1 - Closed systems with treated water (cooling to $14^{\circ} \mathrm{C}$ )

S2 - Dry cold storage

D1 - Phytoplankton produced in outdoor basins using well water

D2 - Phytoplankton produced in indoor 300L cylinders

D3 - Phytoplankton paste purchased from suppliers 


\section{Figures}

Figure 1. Standard purification diagram (recirculation system - treated water)

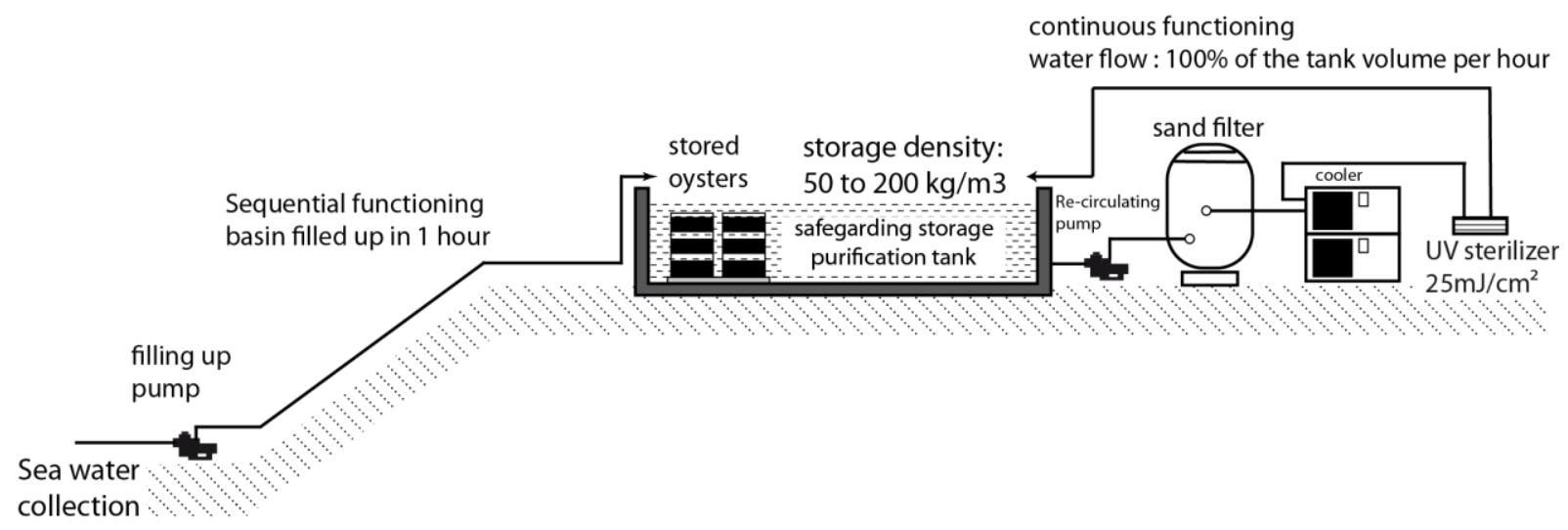

Figure 2. Investment costs (2007 US dollars) per $\mathrm{m}^{3}$ of tank for safeguarding storage option $\mathrm{S} 1$ including the associated equipment required

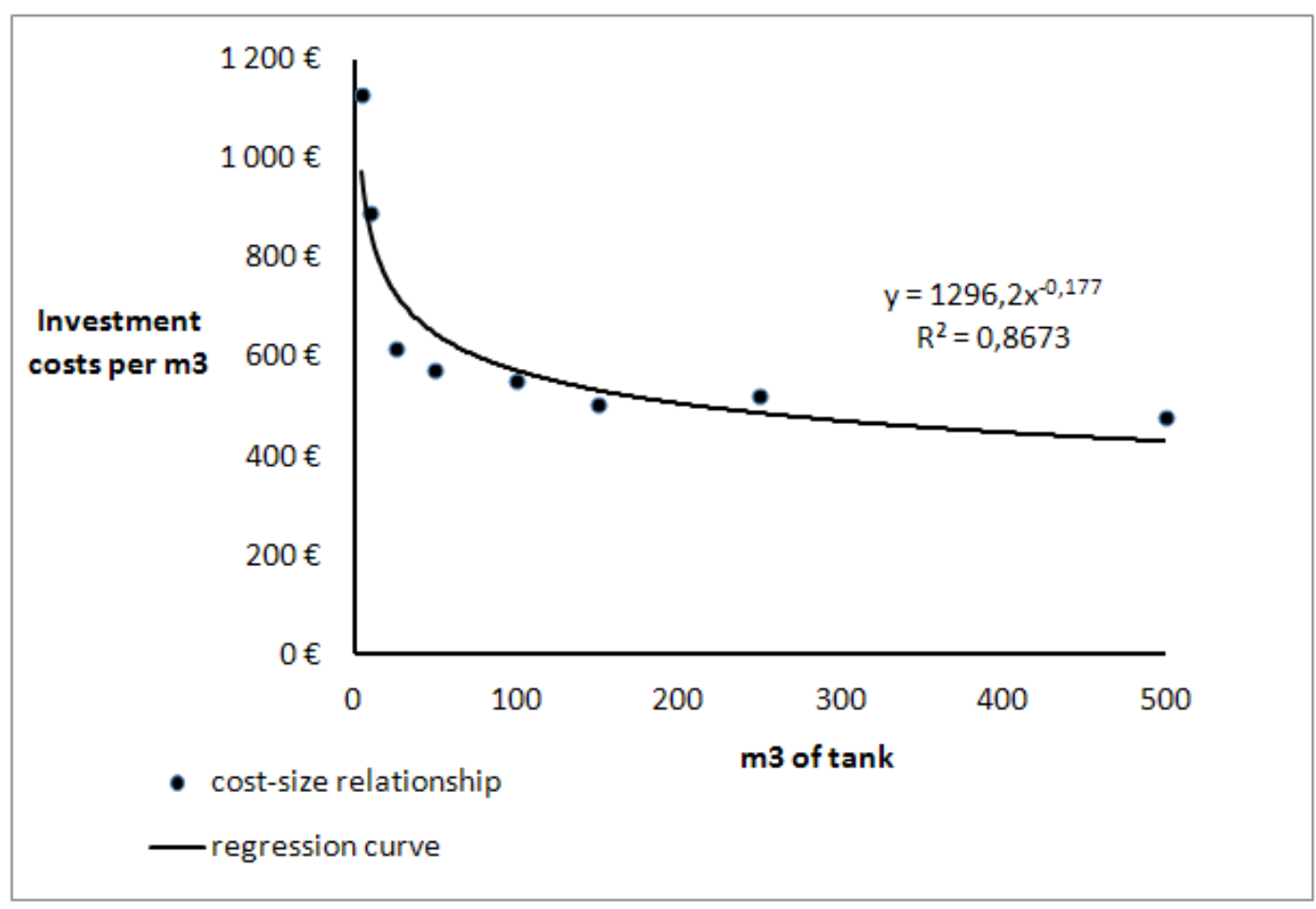


Figure 3. Feasibility frontier of collective investments

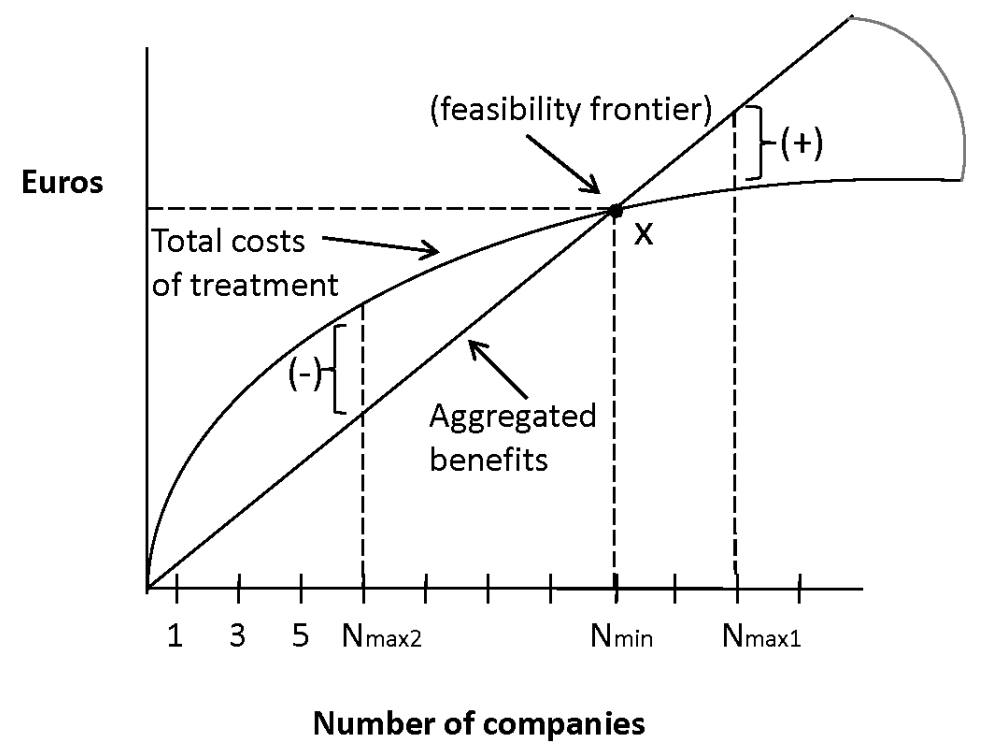

